\title{
PERSAMAAN HUKUM KEBEBASAN BERPOLITIK ANGGOTA TENTARA NASIONAL INDONESIA DAN KEPOLISIAN NEGARA REPUBLIK INDONESIA DALAM PEMILIHAN UMUM DI INDONESIA
}

\section{LEGAL EQUALITY OF POLITICAL FREEDOM THE MEMBERS OF INDONESIAN NATIONAL ARMY AND POLICE OF INDONESIA REPUBLIC IN THE GENERAL ELECTIONS IN INDONESIA}

Basuki Kurniawan,

Fakultas Hukum, Universitas Jember (UNEJ)

Jl. Kalimantan 37 Kampus Tegalboto, Jember, Kotak Pos 159

E-mail: basukikurniawan97@yahoo.com

\section{Abstract}

The members of INA and PIR don't give right to vote and be elected in general elections because there is worried about right to vote and be elected will be bringing on not neutral in general election, with the result that general elections principle is direct, general, secret, honest, and fair will not be achieved if right to vote and be elected is given. Although that worried still be able to debate in theoretical. It is becaused if right to vote and be elected for members of INA and PIR are given, so will not influence the vote result majority in general elections. The concept to give right to vote and be elected for members INA and PIR in general elections need to be implemented, because in the first general elections in 1955 the members of INA and PIR follow to vote and be elected in general election, and than there was not problem happen in thats time. Because of that be alternative thought bargained in this thesis; The concept of legal protection for members INA and PIR in political freedom is looked from human right protection principle is given freedom for members INA and PIR to vote the candidates house representatives, house representative region, house representative people, President and Vice President with free without any pressures from the institution INA and PIR. And than for the members INA and PIR propose their self as candidates the members House Representative, House Representative Region, House Representative People, President and Vice President permitted to be candidate as form of political freedom to every people

Keyword: legal equality, political freedom, general election.

\section{A. PENDAHULUAN}

Negara Indonesia dinyatakan oleh Undang-Undang Dasar Negara Republik Indonesia Tahun 1945 atau disebut UUD NRI Tahun 1945 sebagai negara hukum. ${ }^{1}$ Ini berarti bahwa pada hakikatnya semua orang maupun badan hukum yang berada di wilayah Indonesia, harus tunduk dan patuh pada hukum yang berlaku di negara Indonesia. Alat-alat perlengkapan negara, seperti departemendepartemen dan lembaga negara-lembaga negara dengan instansi-instansi yang berada di bawahnya, perusahaan dalam bentuk Badan Usaha Milik Negara atau Badan Usaha Milik Swasta; tentara, polisi, guru, buruh, petani dan lainnya, demikian juga Lembaga Negara seperti Dewan Perwakilan Rakyat baik di pusat maupun di daerah serta Dewan Perwakilan Daerah semuanya tunduk dan taat pada hukum yang berlaku.

1 Lihat UUD NRI Tahun 1945 Pasal 1 ayat (3) "Negara Indonesia adalah negara hukum”. 
Di dalam Kamus Umum Bahasa Indonesia, yang dinamakan negara adalah organisasi dalam suatu wilayah yang diatur oleh kekuasaan tertinggi yang sah dan ditaati oleh rakyat. ${ }^{2}$ Sedangkan yang dinamakan dengan hukum ialah peraturan resmi yang menjadi pengatur dan dikuatkan oleh pemerintah; undang-undang, peraturan; patokan (kaidah, ketentuan) mengenai peristiwa alam yang tertentu. ${ }^{3}$ Kemudian negara hukum dapat diartikan bahwa semua orang harus menjunjung tinggi hukum, dan tidak ada tempat bagi orang yang mempertahankan haknya dengan kekuatan sendiri.

Telaah teoretikal tentang ontologi negara dan hukum, serta perdebatan tentang makna kedaulatan penting lebih dahulu dikemukakan. A.Hamid S. Attamimi ${ }^{4}$ mengutip pendapat Jellinek merumuskan arti kedaulatan secara singkat, ialah kekuasaan negara yang atas dasar itu mempunyai kemampuan yang penuh untuk secara hukum menentukan dan mengikat dirinya sendiri. Di tempat lain Jellinek menjelaskan bahwa dalam kemampuan untuk menentukan dan mengikat diri sendiri itu terletak unsur yuridis dari kekuasaan negara. Apabila kemampuan tersebut merupakan sesuatu yang bersifat mutlak serta menutup kemungkinan bagi lain-lainnya dan karena itu negara dalam segala seginya dapat menentukan dan mengikat dirinya sendiri, berlaku dimana-mana, dan tidak pernah diperintah siapapun juga, maka hal itu menunjukkan tanda suatu kedaulatan. ${ }^{5}$

Indonesia salah satu negara yang menganut prinsip kedaulatan rakyat, seperti diatur dalam Pasal 1 Ayat (2) UUD NRI Tahun 1945 yang mengamanatkan: "Kedaulatan berada di tangan rakyat dan dilaksanakan menurut Undang-Undang Dasar". Sebagai negara yang menganut prinsip kedaulatan rakyat, maka penyelenggaraan Pemilihan Umum atau biasa disebut dengan Pemilu, merupakan instrumen yang harus ada dan dilaksanakan dengan sebaik-baiknya. Karena Pemilu itu merupakan salah satu aktualisasi dari Kedaulatan Rakyat. Oleh sebab itu, aktualisasi demokrasi dalam sistem ketatanegaraan Indonesia ini harus dijalankan menurut UUD NRI Tahun 1945. Ini sesuai dengan pandangan, bahwa Indonesia adalah negara hukum yang demokratis, atau Indonesia adalah negara demokrasi yang kostitusi. ${ }^{6}$ Demokrasi yang digunakan di Indonesia adalah Demokrasi Pancasila. Demokrasi Pancasila itu sesuai dengan keberadaan kultur masyarakat Indonesia yang majemuk, tentunya pelaksana penegakan kedaulatan rakyat dalam Hak Asasi Manusia itu harus sesuai dengan Demokrasi Pancasila dan UUD NRI Tahun 1945.

Pemilu sebagaimana diatur dalam Pasal 22E Ayat (1) UUD NRI Tahun 1945 menyatakan:

\footnotetext{
Ari Prahasta, Kamus Umum Bahasa Indonesia, (Tangerang Selatan : Scientific Press), hlm. 299. 
(1) Pemilihan umum dilaksanakan secara langsung, umum, bebas, rahasia, jujur dan adil setiap lima tahun sekali.

(2) Pemilihan umum diselenggarakan untuk memilih anggota Dewan Perwakilan Rakyat, Dewan Perwakilan Daerah, Presiden dan Wakil Presiden dan Dewan Perwakilan Rakyat Daerah.

Rumusan Pemilu sebagaimana ditentukan dalam Pasal 1 angka 1 UndangUndang Nomor 15 Tahun 2011 tentang Pemilihan Umum menyatakan:

"Pemilihan umum selanjutnya disebut Pemilu, adalah sarana pelaksanaan kedaulatan rakyat yang diselenggarakan secara langsung, umum, bebas, rahasia, jujur dan adil dalam Negara Kesatuan Republik Indonesia berdasarkan Pancasila dan Undang-Undang Dasar Negara Republik Indonesia Tahun 1945".

UUD NRI Tahun 1945 Pasal 27 Ayat (1) menyatakan: "Segala warga negara bersamaan kedudukannya di dalam hukum dan pemerintahan dan wajib menjunjung hukum dan pemerintahan itu dengan tidak ada kecualinya". Berdasarkan Pasal 27 Ayat (1) tersebut bahwa semua warga negara (termasuk anggota TNI dan Polri) mempunyai kedudukan yang sama di bidang politik, yang berarti bahwa anggota TNI dan Polri memiliki hak yang sama sebagai warga negara untuk memilih dan dipilih dalam Pemilu. Kebebasan tiap warga negara untuk ikut serta dalam berpolitik dilindungi oleh UUD NRI Tahun 1945, karena Indonesia merupakan negara yang berdasarkan hukum. Setiap warga negara Indonesia yang berdiam diri dan tinggal di Indonesia diakui keberadaannya oleh undang-undang untuk ikut berpartisipasi dan berperan aktif untuk mengeluarkan pendapat dan berhak atas kebebasan, berserikat, berkumpul. ${ }^{7}$

Kedudukan militer dalam sejarah kemerdekaan Indonesia sangat berperan penting dalam memproklamirkan kemerdekaan Indonesia. Rakyat berjuang bersama-sama tentara untuk ikut berperang dan mengusir para penjajah dari nusantara. Benny K. Harman ${ }^{8}$ menerangkan bahwa kehadiran militer dalam perpolitikan nasional sebenarnya sudah berlangsung sejak awal kemerdekaan Indonesia. Salah satu karakteristik militer Indonesia adalah berasal dari gerakan perlawanan rakyat yang pada saat itu sedang berjuang mempertahankan kemerdekaan. Dengan demikian, militer Indonesia bukan bentukan politisi sipil, bukan pula warisan penjajahan Belanda atau Jepang. Bahkan bersama politisi sipil (yang berjuang lewat jalur diplomasi), militer bergandeng tangan (dengan menggunakan senjata), mempertahankan kemerdekaan dari serangan Belanda yang bermaksud menjajah kembali.

\footnotetext{
7 Lihat Pasal 28E Ayat (3) UUD NRI Tahun 1945: "Setiap orang berhak atas kebebasan berserikat, berkumpul, dan mengeluarkan pendapat".

8 Benny K. Harman, Konfigurasi Politik dan Kekuasaan Kehakiman di Indonesia, (Jakarta: ELSAM, 1997), hlm. 162.
} 
Hal tersebut kemudian menjadi sebuah karakteristik militer Indonesia adalah "prajurit pejuang" sekaligus "pejuang prajurit". ${ }^{9}$ Ciri khusus tentara Indonesia ini diakui oleh pengamat militer Indonesia, sebagaimana yang dikutip oleh Benny K. Harman tentang pendapat Harold Crouch yang mengatakan:

"Sejarah militer Indonesia adalah lain dari negara lain. Berbeda dengan pengalaman banyak negara dunia ketiga yang tentaranya didirikan oleh penjajah kemudian diambil alih oleh pemerintah nasional sesudah negara itu mendapatkan kemerdekaan, tentara Indonesia dilahirkan pada zaman revolusi untuk melawan penjajah itu, latar belakang yang agak khas itulah yang mempengaruhi persepsi, sikap, dan tingkah laku tentara Indonesia pada zaman berikutnya sehingga sejarah sesudah revolusi juga agak khas". ${ }^{10}$

Sejarah telah mencatat tentang peran serta militer yakni Angkatan Bersenjata Republik Indonesia (ABRI)/Tentara Nasional Indonesia (TNI) ${ }^{11}$ dan Kepolisian Negara Republik Indonesia (Polri) dalam keikutsertaannya dalam kancah perpolitikan semenjak Indonesia masa Pemerintahan Presiden Soekarno atau biasa disebut dengan masa Orde Lama, anggota TNI dan Polri diberikan hak untuk memilih dalam Pemilu. Sebagaimana termaktub dalam Undang-Undang Nomor 7 Tahun 1953 tentang Pemilihan Anggota Konstituante dan Anggota Dewan Perwakilan Rakyat. ${ }^{12}$ Kemudian pada Orde Baru atau pemerintahan Presiden Soeharto, TNI dan Polri tidak diberikan hak untuk memilih dalam pemilihan umum, namun keberadaan ABRI dalam ranah politik diatur secara khusus melalui mekanisme pengangkatan dalam lembaga legislatif dan diatur dalam Undang-Undang Nomor 15 Tahun 1969 tentang Pemilihan Umum Anggota - Anggota Badan Permusyawaratan/ Perwakilan Rakyat. Pada masa reformasi yakni tahun 1998, hak memilih dan dipilih pada Pemilu bagi anggota TNI dan Polri dihilangkan sebagaimana yang diamanatkan oleh Ketetapan Majelis Permusyawaratan Rakyat Nomor VI/MPR/2000 tentang Pemisahan Tentara Nasional Indonesia dan Kepolisian Negara Republik Indonesia dan Ketetapan MPR Nomor VII/MPR/2000 tentang Peran TNI dan Polri. Kemudian Ketetapan MPR No. VII/MPR/2000 mengenai kedudukan TNI pada Pasal 5 menyatakan bahwa:

(1) Kebijakan politik negara merupakan dasar kebijakan dan pelaksanaan tugas Tentara Nasional Idonesia.

(2) Tentara Nasional Indonesia bersikap netral dalam kehidupan politik dan tidak melibatkan diri dalam kehidupan politik praktis.

(3) Tentara Indonesia mendukung tegaknya demokrasi, menjunjung tinggi hukum dan hak asasi manusia.

9 Ibid, hlm. 162.

10 Ibid, hlm. 163.

11 Sejak tanggal 12 April 1999, sebutan ABRI diganti menjadi TNI, berdasar Skep Panglima TNI nomor: Skep/259/P/IV/1999.

12 Lihat UU No. 7 Tahun 1953 tentang Pemilihan Anggota Konstituante dan Anggota Dewan Perwakilan Rakyat, Pasal 1 Ayat (1) menyatakan: “ Anggota Konstituante dan anggota Dewan Perwakilan Rakyat dipilih oleh warga negara Indonesia, yang dalam tahun pemilihan berumur genap 18 tahun atau yang sudah kawin lebih dahulu". 
(4) Anggota Tentara Nasional Indonesia tidak menggunakan hak memilih dan dipilih. Keikutsertaan Tentara Nasional Indonesia dalam menentukan arah kebijakan nasional disalurkan melalui Majelis Permusyawaratan Rakyat paling lama sampai dengan tahun 2009.

(5) Anggota Tentara Nasional Indonesia hanya dapat menduduki jabatan sipil setelah mengundurkan diri atau pensiun dari dinas ketentaraan.

Selanjutnya Pasal 10 menyatakan, bahwa:

(1) Kepolisian Negara Republik Indonesia bersikap netral dalam kehidupan politik dan tidak melibatkan diri pada kegiatan politik praktis.

(2) Anggota Kepolisian Negara Republik Indonesia tidak mengggunakan hak memilih dan dipilih. Keikutsertaan Kepolisian Negara Republik Indonesia dalam menentukan arah kebijakan nasional disalurkan melalui Majelis Permusyawaratan Rakyat paling lama sampai dengan tahun 2009.

(3) Anggota Kepolisian Negara Republik Indonesia dapat menduduki jabatan di luar kepolisian setelah mengundurkan diri atau pensiun dari dinas kepolisian.

Kedudukan hak politik TNI juga dinyatakan pada Undang-Undang Nomor 34 Tahun 2004 tentang Tentara Nasional Indonesia Pasal 39 sebagai berikut:

Prajurit dilarang terlibat dalam:

1. Kegiatan menjadi anggota partai politik;

2. Kegiatan politik praktis;

3. Kegiatan bisnis;

4. Kegiatan untuk dipilih menjadi anggota legislatif dalam pemilihan umum dan jabatan politik lainnya.

Ditambahkan pula dengan Undang-Undang Nomor 2 Tahun 2002 tentang Kepolisian Negara Republik Indonesia Pasal 28 yang menyatakan sebagai berikut: (1) Kepolisian Negara Republik Indonesia bersikap netral dalam kehidupan politik dan tidak melibatkan diri pada kegiatan politik praktis.

(2) Anggota Kepolisian Negara Republik Indonesia tidak menggunakan hak memilih dan dipilih.

(3) Anggota Kepolisian Negara Republik Indonesia dapat menduduki jabatan di luar kepolisian setelah mengundurkan diri atau pensiun dari dinas kepolisian.

Ketidakikutsertaan TNI dan Polri dalam politik khususnya hak memilih dan dipilih dalam Pemilu itu dikarenakan reformasi Indonesia yang didorong oleh semangat bangsa Indonesia untuk menata kehidupan dan masa depan bangsa yang lebih baik telah menghasilkan perubahan mendasar dalam sistem ketatanegaraan dan kenegaraan. Perubahan tersebut telah ditindaklanjuti antara lain melalui penataan kelembagaan sesuai dengan perkembangan lingkungan dan tuntutan tugas ke depan. Perubahan pada sistem kenegaraan berimplikasi pula terhadap Tentara Nasional Indonesia, antara lain adanya pemisahan Tentara 
Nasional Indonesia dan Kepolisian Negara Republik Indonesia, yang menyebabkan perlunya penataan kembali peran dan fungsi masing-masing. Ketetapan Majelis Permusyawaratan Rakyat Nomor VII/MPR/2000 tentang Peran Tentara Nasional Indonesia dan Peran Kepolisian Negara Republik Indonesia, sekaligus menjadi referensi yuridis dalam mengembangkan suatu undang-undang yang mengatur tentang Tentara Nasional Indonesia. ${ }^{13}$ Bahwa peran sosial politik dalam dwifungsi Angkatan Bersenjata Republik Indonesia menyebabkan terjadinya penyimpangan peran dan fungsi Tentara Nasional Indonesia dan Kepolisian Negara Republik Indonesia yang berakibat tidak berkembangnya sendi-sendi demokrasi dalam kehidupan berbangsa, bernegara, dan bermasyarakat. ${ }^{14}$

Di Indonesia, jaminan warganegara terhadap kebebasan berserikat, berkumpul dan mengeluarkan pikiran diatur dalam Pasal 28E Ayat (3) UUD NRI Tahun 1945 yang menyatakan bahwa: "Setiap orang berhak atas kebebasan berserikat, berkumpul, dan mengeluarkan pendapat". Namun diamanatkan UUD NRI Tahun 1945 dalam Pasal 28J Ayat (2) : "Dalam menjalankan hak dan kebebasannya, setiap orang wajib tunduk kepada pembatasan yang ditetapkan dengan undang-undang dengan maksud semata-mata untuk menjamin pengakuan serta penghormatan atas hak dan kebebasan orang lain dan untuk memenuhi tuntutan yang adil sesuai dengan pertimbangan moral, nilai-nilai agama, keamanan, dan ketertiban umum dalam suatu masyarakat demokratis."

Selanjutnya, agar kajian ini lebih terarah, maka lingkup kajian dibatasi dengan memberikan klarifikasi atas judul tesis : Persamaan Hukum Berpolitik Kebebasan Berpolitik Anggota Tentara Nasional Indonesia dan Kepolisian Negara Republik Indonesia Dalam Pemilihan Umum di Indonesia' ini sebagai berikut. Pertama, bahwa yang dimaksud dengan Persamaan Hukum dalam tulisan ini adalah kesetaraan hak dan posisi yang seimbang antara anggota Tentara Nasional Indonesia dan Kepolisian Negara Republik Indonesia dengan Pegawai Negeri Sipil (PNS) serta warga sipil lainnya dalam kedudukannya sebagai warga negara. Kedua, bahwa yaang dimaksud dengan Kebebasan Berpolitik Anggota Tentara Nasional Indonesia dan Kepolisian Negara Republik Indonesia adalah hak memilih dan dipilih bagi anggota TNI dan Polri dalam pemilu, hak anggota TNI dan Polri untuk memilih anggota legislatif, Presiden dan Wakil Presiden, sedangkan untuk hak dipilih yakni anggota TNI dan Polri dapat mencalonkan diri sebagai calon anggota legislatif, Presiden dan Wakil Presiden. Kebebasan Berpolitik juga mempunyai makna hak politik anggota TNI dan Polri untuk memilih dan dipilih dalam pemilu. Ketiga, bahwa yang dimaksud dengan Dalam Pemilihan Umum di Indonesia dalam judul tesis ini adalah dalam pemilihan umum untuk memilih Anggota DPR, DPRD, DPD, Presiden dan Wakil Presiden sesuai dengan UU Pemilu dan UUD NRI Tahun 1945.

\footnotetext{
13 Penjelasan Undang-Undang Nomor 34 Tahun 2004 Tentang Tentara Nasional Indonesia.

14 Lihat konsideran Ketetapan Majelis Permusyawaratan Rakyat Republik Indonesia Nomor VI/MPR/2000 tentang Pemisahan Tentara Nasional Indonesia dan Kepolisian Negara Republik Indonesia.
} 
Atas dasar pemikiran dan pembatasan-pembatasan sebagaimana tersebut, melalui penyusunan tesis ini, peneliti hendak mengkaji dan menganalisis secara lebih dalam mengenai PERSAMAAN HUKUM KEBEBASAN BERPOLITIK ANGGOTA TENTARA NASIONAL INDONESIA DAN KEPOLISIAN NEGARA REPUBLIK INDONESIA DALAM PEMILIHAN UMUM DI INDONESIA.

\section{B. PEMBAHASAN}

Pengaturan tentang hak memilih serta dipilih anggota TNI dan Polri pada dasarnya dipengaruhi oleh perkembangan demokratisasi di Indonesia. Dalam pembahasan ini, pendekatan sejarah digunakan dalam rangka penelaahan sejumlah peristiwa-peristiwa hukum sejak zaman Indonesia merdeka yang disusun secara kronologis. Dalam hal ini, hukum sebagai gejala sejarah berarti tunduk pada pertumbuhan yang terus menerus. Pengertian tumbuh tersebut mempunyai 2 (dua) arti yaitu perubahan dan stabilitas. Hukum tumbuh, berarti bahwa terdapat hubungan yang erat, sambung-menyambung atau hubungan yang tak terputus-putus antara hukum pada masa kini dan hukum pada masa lampau. Hukum pada masa kini dan hukum pada masa lampau merupakan satu kesatuan. Ini dapat dimengerti bahwa hukum pada masa kini, hanya dengan penyelidikan sejarah, bahwa mempelajari hukum secara ilmu pengetahuan harus mempelajari sejarah. Dalam kaitan ini, sejarah pengaturan hukum, mempunyai arti penting dalam rangka pembinaan hukum nasional, oleh karena usaha pembinaan hukum tidak saja memerlukan bahan-bahan tentang perkembangan hukum masa kini saja, akan tetapi juga bahan-bahan mengenai perkembangan dari masa lampau. Melalui pendekatan sejarah, diharapkan mampu menjajaki berbagai aspek politik hukum Indonesia pada masa lalu, yang mana akan dapat memberikan bantuan untuk memahami kaidah-kaidah serta institusi-institusi hukum yang ada dewasa ini dalam masyarakat bangsa kita.

\section{Hak Memilih serta Dipilih Anggota TNI dan Polri dalam Pemilihan Umum Era Orde Lama (Tahun 1945- 1970)}

Sesudah Proklamasi Kemerdekaan pada tanggal 17 Agustus 1945, berdasarkan Aturan Peralihan Undang-Undang Dasar 1945 (sebelum perubahan), kekuasaan negara dijalankan sepenuhnya oleh Presiden, kecuali kekuasaan kehakiman. Undang-Undang Dasar 1945 sendiri hanya memuat dua Pasal mengenai Angkatan Perang dan pembelaan negara, yaitu Pasal 10 UUD 1945 yang menyatakan bahwa: "Presiden memegang kekuasaan tertinggi atas Angkatan Darat, Angkatan Laut", dan Pasal 30 UUD 1945 yang menentukan bahwa:

(1) Tiap-tiap warga negara berhak dan wajib ikut serta dalam usaha pembelaan negara.

(2) Syarat- syarat tentang pembelaan diatur dengan undang-undang.

Tidak mengherankan perkembangan tentara Indonesia dalam negara Republik Indonesia lebih banyak ditentukan oleh dinamika jalannya revolusi perjuangan 
bangsa daripada oleh ketentuan Undang-Undang Dasar. ${ }^{15}$

Pada tanggal 22 Agustus 1945, Panitia Persiapan Kemerdekaan Indonesia membentuk Komite Nasional Indonesia. Ismail Suny ${ }^{16}$ menerangkan bahwa pada tanggal 29 Agustus 1945 Panitia Persiapan Kemerdekaan Indonesia telah dibubarkan oleh Presiden dan sebagai gantinya telah dibentuk Komite Nasional Indonesia Pusat, yang lebih dikenal dengan KNIP. Badan ini, sesuai dengan Pasal IV Aturan Peralihan adalah hanya pembantu Presiden, sama sekali tidak melaksanakan tugas-tugas perundang-undangan baik sendiri, maupun ikut bersama-sama dengan Presiden (medewet-gevende-bevogheid).

Belum tiga bulan setelah Proklamasi Kemerdekaan dan berlakunya UndangUndang Dasar 1945, maka bangsa Indonesia mengalami apa yang disebut "Verfassung wandlung", yaitu ada perubahan mendasar dalam pelaksanaan Undang-Undang Dasar yang pada hakekatnya menyimpang dari isi UndangUndang Dasar 1945 tanpa merubah secara formal Undang-Undang Dasar $1945 \mathrm{itu}$ sendiri. ${ }^{17}$ Pada tanggal 16 Oktober 1945, atas usul Komite Nasional Indonesia Pusat (KNIP), kemudian dikeluarkanlah Maklumat Wakil Presiden No. X oleh Moh. Hatta yang memberikan kekuasaan legislatif kepada KNIP. Maklumat No. X kemudian menetapkan bahwa: "Komite Nasional Pusat, sebelum terbentuknya Majelis Permusyawaratan Rakyat dan Dewan Perwakilan Rakyat diserahi kekuasaan legislatif dan ikut menetapkan garis-garis besar dari pada haluan Negara".18

Kemudian dengan Maklumat Pemerintah tanggal 14 Nopember 1945 diumumkan, bahwa Menteri-menteri negara (yang menurut Undang-Undang Dasar 1945 merupakan pembantu Presiden dan bertanggung jawab kepadanya), menjadi lembaga pemerintah yang bertanggungjawab kepada Komite Nasional cq. Badan Pekerja KNIP dalam fungsinya sebagai Badan Perwakilan Rakyat. Sebelumnya, pada tanggal 3 Nopember 1945 dikeluarkan Maklumat Wakil Presiden yang menganjurkan dibentuknya partai-partai politik. Dengan demikian sistem pemerintahan presidensial berubah menjadi sistem pemerintahan yang bertanggungjawab kepada parlemen dengan banyak partai. Maka mulai berlakulah sistem demokrasi liberal dengan faham supremasi sipilnya. Hal ini berarti bahwa kebijaksanaan-kebijaksanaan pokok kenegaraan dan pemerintahan diputuskan oleh lembaga-lembaga sipil yang pejabatnya adalah orang-orang sipil. Tentara adalah sebagai alat negara belaka yang didudukkan dibawah dan dikendalikan oleh pemerintah (sipil) yang berkuasa. ${ }^{19}$

Dalam maklumat tersebut dinyatakan bahwa perlunya berdirinya partaipartai politik sebagai bagian dari demokrasi, serta rencaNa pemerintah

\footnotetext{
15 A.S.S. Tambunan dkk, op.cit, hlm. 10.

16 Ismail Sunny, Pergeseran Kekuasaan Eksekutif Suatu Penyelidikan dalam Hukum Tatanegara, (Jakarta: Aksara Baru, 1986), hlm. 27.

17 A.S.S. Tambunan dkk, op. cit, hlm. 12.

18 Ismail Sunny, op. cit, hlm. 28.

19 A.S.S. Tambunan dkk, op.cit, hlm. 13
} 
menyelenggarakan Pemilu pada Januari 1946. Maklumat Muhammad Hatta berdampak luas, melegitimasi partai-partai politik yang telah terbentuk sebelumnya dan mendorong terus lahirnya partai-partai politik baru. ${ }^{20}$

Semangat hendak diselenggarakannya Pemilu pertama sebagai amanat Maklumat Pemerintah ternyata tidak dapat dilaksanakan, karena Negara sedang dihadapkan pada pilihan mempertahankan kemerdekaan, disamping itu memang belum tersedia peraturan perundang-undangan yang mengatur Pemilu. Soedarsono mengemukakan setidaknya ada 4 (empat) hal penyebab tidak dilaksanakannya Maklumat tersebut yaitu:

a. Perangkat Undang-Undang Pemilu belum dibuat, dengan demikian pemerintah belum siap menyelenggarakan Pemilu.

b.Belum stabilitasnya kondisi keamanan negara akibat konflik internal antar kekuatan politik yang ada pada waktu itu.

c. Ancaman gangguan dari luar.

d. Para pemimpin Negara lebih disibukkan oleh urusan konsolidasi. ${ }^{21}$

Mencermati aspek kesejarahannya, Pemilu Indonesia 1955 adalah Pemilihan Umum pertama di Indonesia dan diadakan pada tahun 1955. Pemilu ini dapat dikatakan sebagai Pemilu Indonesia yang paling demokratis. Bahkan Indonesianis seperti Herbert Feith menilai bahwa Pemilu 1955 adalah yang paling demokratis dibandingkan pemilu sepanjang pemerintahan Orde Baru. Walaupun Pemilu 1955 dilaksanakan saat keamanan negara masih kurang kondusif, 22 namun anggota Angkatan Bersenjata (TNI) dan Polisi diikutsertakan untuk memilih dan dipilih dalam Pemilu yang pertama kali pada tahun 1955. Kemudian mereka (anggota TNI dan Polri) yang bertugas di daerah rawan kemudian diberikan kesempatan untuk datang ke tempat pemilihan dan pada akhirnya Pemilu berlangsung dalam siatuasi yang aman.

Soedarsono berpendapat bahwa patut dibanggakan Pemilu yang pertama kali tersebut berhasil diselenggarakan dengan aman, lancar, jujur dan adil serta sangat demokratis. ${ }^{23}$ Demikian pula halnya bahwa Pemilu pada tahun 1955 merupakan pelajaran yang sangat berharga, dimana etika revitalitas untuk merebut dukungan dari masyarakat dijunjung tinggi, dan sosok pejabat negara yang sedang berkuasa tidak dianggap sebagai pesaing yang menakutkan karena tidak menggunakan kesempatan dan kekuasaannya untuk memenangkan Pemilu dengan segala cara. Dan hal penting lainnya bahwa dalam Pemilu tersebut, tidak ada kelompok warga negara yang dikecualikan, termasuk Tentara Nasional Indonesia (TNI) dan Kepolisian Negara Republik Indonesia (Polri) juga memiliki

\footnotetext{
20 Ibid.

${ }^{21}$ Soedarsono, Mahkamah Konstitusi Sebagai Pengawal Demokrasi, (Jakarta: Sekretariat Jenderal dan Kepaniteraan Mahkamah Konstitusi, 2005), hlm. 1.

${ }^{22}$ Keadaan ini disebabkan karena beberapa daerah dirundung kekacauan oleh DI/TII (Darul Islam/ Tentara Islam Indonesia) khususnya pimpinan Kartosuwiryo.

23 Soedarsono, loc. cit.
} 
hak suara yang sama dengan warga negara lainnya. ${ }^{24}$

Pengaturan tentang hak pilih bagi anggota Angkatan Bersenjata dan Polri ditegaskan dalam Undang-Undang No. 7 Tahun 1953 tentang Pemilihan Anggota Konstituante dan Anggota Dewan Perwakilan Rakyat. Pada Pasal 1 Ayat (1) dinyatakan bahwa:

Anggota Konstituante dan anggota Dewan Perwakilan Rakyat dipilih oleh warga negara Indonesia, yang dalam tahun pemilihan berumur genap 18 tahun atau yang sudah kawin lebih dahulu.

Pasal 3 Ayat (1) menentukan bahwa:

Pemerintah mengadakan ketentuan-ketentuan khusus untuk memungkinkan pelaksanaan hak pilih bagi anggota-anggota Angkatan Perang dan Polisi, yang pada hari dilakukan pemungutan suara sedang dalam menjalankan tugas operasi atau tugas biasa di luar tempat kedudukannya dan apabila perlu dengan mengadakan dalam waktu sependek-pendeknya pemungutan suara susulan untuk mereka itu.

Mencermati hal tersebut, maka pada era Orde Lama anggota TNI dan Polri diberikan hak yang sama sebagai warga negara dalam ranah politik. Hal ini dikarenakan pada era revolusi kemerdekaan, Angkatan Bersenjata dan Polri senantiasa menghadapi permasalahan sosial, politik, dan ekonomi. Sehingga mereka memiliki kedewasaan dalam pelaksanaan tugasnya dan tidak memiliki tendensi kekuasaan. Perlu dicermati bahwa meskipun anggota TNI dan Polri memilih beragam partai, namun institusi Angkatan Bersenjata dan Polri tetap utuh. Adapun mengenai politisasi Angkatan Bersenjata dan Polri tidaklah jadi pada saat pemilu, melainkan ketika terjadi persoalan dalam hubungan antara pemerintah pusat dan daerah. ${ }^{25}$ Kedewasaan TNI dan Polri waktu itu menjadi cerminan dalam kedewasaan politik TNI dan Polri untuk ikut menentukan masa depan bangsa Indonesia yang lebih baik.

Hal tersebut bermakna bahwa Pemilu pertama nasional di Indonesia pada tahun 1955 telah mendekati kriteria demokratis, sebab selain jumlah parpol tidak dibatasi, berlangsung dengan langsung umum bebas rahasia (luber), serta mencerminkan pluralisme dan representativeness karena melibatkan seluruh elemen masyarakat, termasuk didalamnya adalah anggota Angkatan Bersenjata dan Kepolisian. Ketiadaaan diskriminasi dalam Pemilu 1955 membuktikan bahwasannya demokrasi yang dijalankan pada era Orde Lama berjalan dengan baik. Dan semua elemen masyarakat dapat menyuarakan pilihannya dalam Pemilu.

\section{Hak Memilih serta Dipilih TNI dan Polri dalam Pemilihan Umum Era Orde}

\footnotetext{
${ }^{24}$ Ibnu Tritjahjo, Pengaturan Pemisahan Pemilu Nasional dan Lokal Dalam Rangka Penyeleggaraan Otonomi Daerah yang Demokratis, (Disertasi), (Malang: Universitas Brawijaya, 2007), hlm. 52.

25 Jurnal Dinamika Hukum, Vol. 11 No. 1 Januari 2011, hlm. 53.
} 


\section{Baru (Tahun 1971-1997).}

Pada era Orde Baru, lembaga TNI dan Polri dijadikan sebagai alat untuk mempertahankan rezim pemerintahan yang dipimpin oleh Presiden Soeharto yang notabene berasal dari kalangan militer. Untuk mempertahankan kekuasaannya, Presiden Soeharto tidak hanya menjadikan TNI dan Polri sebagai alat pertahanan dan keamanan, tetapi juga menjadikannya sebagai kekuatan sosial, politik, dan ekonomi yang punya akses berlebih untuk mengatur kehidupan berbangsa dan bernegara melalui format dwifungsi ABRI. ${ }^{26}$

Pengaturan Dwifungsi ABRI dalam undang-undang baru dimulai pada era Pemerintahan Presiden Soeharto, walaupun sebelumnya beberapa peraturan perundang-undangan telah menyinggung kedudukan ABRI sebagai golongan fungsional seperti umpamanya UU No. 7 Tahun 1957 tentang Dewan Nasional. Peraturan perundangan zaman Orde Baru yang menyangkut dwifungsi ABRI dimulai dengan Ketetapan MPRSNomor XXIV/MPRS/1966 yang kemudian disusul Undang- Undang Nomor 15 tahun 1969 tentang Pemilihan Umum dan UU No. 16 Tahun 1969 tentang Susunan dan Kedudukan MPR, DPR, dan DPRD yang antara lain mengatakan:27

Mengingat dwifungsi ABRI sebagai alat negara dan kekuatan sosial yang harus kompak bersatu dan merupakan kesatuan untuk dapat menjadi pengawal dan pengaman Pancasila dan Undang-Undang Dasar 1945 yang kuat dan sentosa

Kemudian Ketetapan MPR No. IV/MPR/1978 tentang Garis-Garis Besar Haluan Negara mengukuhkan Dwifungsi ABRI sebagai salah satu modal dasar pembangunan nasional dengan kalimat:

Angkatan Bersenjata Republik Indonesia sebagai kekuatan pertahanan keamanan dan kekuatan sosial yang tumbuh dari rakyat bersama rakyat menegakkan kemerdekaan bangsa dan negara.

Sebagai lanjutan Ketetapan MPR No.IV/MPR/1978 pada tanggal 19 September 1982 telah diundangkan Undang-Undang Nomor 20 Tahun 1982 tentang Ketentuan-ketentuan Pokok Pertahanan Keamanan Negara. Pasal 26 Undang-undang itu menyatakan:

Angkatan bersenjata mempunyai fungsi sebagai kekuatan pertahanan keamanan negara dan sebagai kekuatan sosial.

Dalam Penjelasan Pasal ini dirumuskan :

Fungsi Angkatan bersenjata sebagai kekuatan sosial sudah ada sejak kelahirannya serta merupakan bagian dari hasil proses perjuangan dan pertumbuhan bangsa Indonesia yang telah dirumuskan dalam marga kesatu

\footnotetext{
${ }^{26}$ Setiajeng Kadarsih dan Tedi Sudrajat, loc. cit.

27 A.S.S. Tambunan dkk, op. cit, hlm. 120.
} 
sampai marga ketiga pada Saptamarga dan dinyatakan sebagai salah satu modal dasar pembangunan nasional dalam Garis-garis Besar Haluan Negara (Ketetapan Majelis Permusyawaratan Rakyat Nomor IV/MPR/1978).

Mencermati pengaturan tersebut, maka dalam kurun waktu Orde Baru, dapat dikatakan bahwa militer turut mendominasi kehidupan sosial-politik nasional dengan menggunakan berbagai justifikasi, seperti konsep Dwifungsi ABRI melalui mekanisme pengangkatan dalam lembaga legislatif, bukan melalui Pemilu. Hal ini memiliki makna bahwa hak pilih yang melekat pada anggota TNI dan Polri mulai digerus dan dipolitisir oleh penguasa. Hal ini kemudian berdampak pada pencitraan negatif dalam diri institusi TNI dan Polri karena diberi akses masuk ke dalam lembaga Legislatif dan Eksekutif melalui mekanisme yang tidak demokratis, serta kemudian dianggap menyalahgunakan kekuasaannya untuk kepentingan penguasa. Korps Militer (TNI dan Polri) masa Orde Baru menjadi golongan fungsional yang sudah disediakan tempat di lembaga Legislatif, tanpa harus melakukan Pemilu terlebih dahulu. Walaupun pada kenyataannya hak pilih dan dipilih anggota TNI dan Polri pada masa Pemerintahan Presiden Soeharto di hapus. Sehingga kedudukan spesial yang dimiliki oleh ABRI seakan pada masa itu menciderai asas Luber dan Jurdil.

\section{Hak Memilih serta Dipilih Anggota TNI dan Polri dalam Pemilihan Umum Era Reformasi (Tahun 1999- sekarang).}

Reformasi yang digulirkan pada tahun 1998, hakekatnya sebagai upaya menata kembali kehidupan berbangsa dan bernegara. Pertama-tama yang dilakukan adalah dengan melakukan perubahan terhadap UUD 1945 oleh MPR sesuai ketentuan yang diatur dalam Pasal 37 UUD 1945. Perubahan terhadap UUD 1945 tersebut dilakukan mulai tahun 1999 sampai dengan tahun 2002, yaitu dalam empat tahap perubahan.

Empat kali perubahan tersebut materi UUD 1945 telah mengalami perubahan secara besar-besaran dan dengan perubahan tersebut, dapat dikatakan UUD 1945 telah mengalami perubahan yang sangat mendasar. ${ }^{28}$ Secara substantif perubahan yang telah terjadi atas UUD 1945 telah menjadikan konstitusi Proklamasi itu menjadi konstitusi yang baru sama sekali meskipun tetap dinamakan sebagai Undang-Undang Dasar 1945.29

Ditinjau dari aspek normanya, reformasi TNI dan Polri terkait dengan hak memilih dan dipilih dalam proses politik diawali dengan dikeluarkannya TAP MPR No. VI/2000 tentang Pemisahan TNI dan Polri serta Tap MPR No. VII/2000 tentang Peran TNI dan Polri. Adapun peraturan yang mengatur hak pilih anggota TNI tertuang dalam Tap MPR No.VII/MPR/2000 Pasal 5 Ayat (2) dan (4) yang menentukan:

\footnotetext{
28 Jimly Asshiddiqie, Konstitusi \& Konstitusionalisme Indonesia...., op. cit, hlm. 58.

29 Ibid.
} 
(2) TNI bersikap netral dalam kehidupan politik dan tidak melibatkan diri dalam kehidupan politik praktis.

(4) Anggota TNI tidak menggunakan hak memilih dan dipilih. Keikutsertaan TNI dalam menentukan arah kebijakan nasional disalurkan melalui MPR paling lama sampai dengan tahun 2009.

Peraturan yang mengatur hak pilih anggota Polri tertuang dalam Pasal 10 ayat (1) dan (2) Tap MPR No. VII/MPR/2000 yang menentukan:

(1) Polri bersikap netral dalam kehidupan politik dan tidak melibatkan diri dalam kehidupan politik praktis.

(2) Anggota Polri tidak menggunakan hak memilih dan dipilih. Keikutsertaan Polri dalam menentukan arah kebijakan nasioal disalurkan melalui MPR paling lama sampai dengan tahun 2009.

Peraturan-peraturan tersebut pada prinsipnya bertujuan agar tercipta sikap profesional dari kedua institusi ini dalam menjalankan tugas dan wewenangnya.

Mencermati konsepsi tentang netralitas politik tersebut, maka pemerintah kemudian melakukan perubahan mendasar terhadap hak pilih serta dipilih TNI dan Polri sebagaimana di atur dalam Pasal 28 Undang-Undang No. 2 tahun 2002 tentang Kepolisian Republik Indonesia yang menyatakan sebagai berikut:

(1) Kepolisian Negara Republik Indonesia bersikap netral dalam kehidupan politik dan tidak melibatkan diri pada kegiatan politik praktis.

(2) Anggota Kepolisian Negara Republik Indonesia tidak menggunakan hak memilih dan dipilih.

(3) Anggota Kepolisian Negara Republik Indonesia dapat menduduki jabatan di luar kepolisian setelah mengundurkan diri atau pensiun dari dinas kepolisian.

Selanjutnya Pasal 39 Undang-Undang No. 34 tahun 2004 tentang Tentara Nasional Indonesia juga menyatakan :

Prajurit dilarang terlibat dalam:

1. Kegiatan menjadi anggota partai politik;

2. Kegiatan politik praktis;

3. Kegiatan bisnis;

4. Kegiatan untuk dipilih menjadi anggota legislatif dalam pemilihan umum dan jabatan politik lainnya.

Pasal 326 UU Nomor 8 Tahun 2012 tentang Pemilihan Umum Anggota DPR, DPD, dan DPRD. Pasal tersebut menyatakan: " Dalam Pemilu tahun 2014, anggota Tentara Nasional Indonesia dan anggota Kepolisian Negara Republik Indonesia tidak menggunakan haknya untuk memilih".

Melihat sejarah dari pengaturan bagi anggota TNI dan Polri di bidang berpolitikan, maka terdapat makna bahwa pemerintah telah menghilangkan hak dasar berupa hak pilih dan dipilih bagi anggota TNI dan Polri guna menciptakan 
situasi yang diinginkan oleh negara. Bahwa peran sosial politik dalam dwifungsi Angkatan Bersenjata Republik Indonesia menyebabkan terjadinya penyimpangan peran dan fungsi Tentara Nasional Indonesia dan Kepolisian Negara Republik Indonesia yang berakibat tidak berkembangnya sendi-sendi demokrasi dalam kehidupan berbangsa, bernegara, dan bermasyarakat. ${ }^{30}$ Penyimpangan yang dikhawatirkan tentang adanya hak pilih dan dipilih TNI serta Polri dalam Pemilu kurang mempunyai dasar yang kuat, dikarenakan di era demokrasi pada saat ini sudah terjadi keseimbangan checks and balances antar Lembaga Negara. Makna dari demokrasi adalah memberikan keleluasaan bagi semua warga negara untuk ikut serta dalam memajukan negara, dan anggota TNI dan Polri juga termasuk warga negara yang wajib dilindungi hak politiknya.

Kekhawatiran politisi sipil akan terjadi tindakan ketidaknetralan TNI dan Polri dalam Pemilu juga masih kurang mempunyai dasar yang kuat, karena sesuai dengan teori Demokrasi dan Pemilu seharusnya setiap warga negara diakui kedudukannya untuk ikut serta dalam Pemilu. Kemudian di tengah masa demokrasi Indonesia yang semakin dewasa dan semakin mapan, tentunya TNI dan Polri akan tetap netral khususnya dalam Pemilu. Namun hak asasi TNI dan Polri sebagai warga negara Indonesia yang juga mempunyai hak untuk memilih dan dipilih dalam Pemilu tidak seharusnya dihilangkan sama sama sekali. Karena hal tersebut bertentangan dengan UUD NRI Tahun 1945 dan UU No. 39 Tahun 1999 tentang Hak Asasi Manusia. Hak Asasi setiap warga negara Indonesia sudah dijamin dan diakui sebagai hak yang melekat dan hak yang tidak dapat dikurangi. Hal tersebut juga berlaku bagi anggota TNI dan Polri yang mempunyai hak pilih dan dipilih dalam Pemilu yang seharusnya tidak dapat dihilangkan atau dikurangi.

\section{Perlindungan Hukum Terhadap Hak Memilih serta Dipilih bagi Anggota TNI dan Polri dengan Konsepsi Hak Asasi Manusia dan UUD NRI Tahun 1945.}

Pengaturan tentang hak pilih dan dipilih dalam perspektif pemerintah, pada hakikatnya merupakan upaya untuk memperoleh kepastian hukum guna membatasi kekuasaan terhadap kemungkinan bergeraknya kekuasaan atas nalurinya sendiri, yang pada akhirnya mengarah pada penyalahgunaan kekuasaan (abuse of power). Konsep pembatasan dalam konteks negara hukum pada awalnya dikemukakan oleh Plato melalui konsepsi nomoi yaitu suatu negara di mana semua orang tunduk kepada hukum, termasuk juga penguasa atau rakyat untuk mencegah agar mereka tidak bertindak secara sewenang-wenang. Gagasan bahwa kekuasaan harus dibatasi dikemukakan juga oleh Lord Acton dalam Setiajeng Kadarsih dan Tedi Sudrajat, yang mengingatkan bahwa pemerintahan selalu diselenggarakan oleh manusia dan bahwa pada manusia itu tanpa kecuali melekat banyak kelemahan. Dalilnya yang kemudian termashur adalah "manusia yang mempunyai kekuasaan cenderung untuk menyalahgunakan kekuasaan itu, tetapi manusia yang mempunyai kekuasaan tak terbatas pasti akan menyalahgunakan

\footnotetext{
${ }^{30}$ Lihat Konsideran Tap MPR No. VI/MPR/2000 huruf d.
} 
secara tak terbatas pula"(Power tends to corrupt, but absolute power corrupt absolutely)". ${ }^{31}$

Berdasarkan hal tersebut, maka pembatasan kekuasaan memiliki korelasi yang erat dengan upaya membatasi perilaku dari penguasa, dan untuk dapat menegaskan aspek kepastian hukumnya, maka didalam setiap pengaturan memiliki pembatasan terhadap kebelakuannya. Artinya tidak ada satupun peraturan yang keberlakuannya sepanjang zaman dan memenuhi kebutuhan realitas sosial yang terus berubah, sehingga setiap perubahan pada hakikatnya merupakan konsekuensi logis bagi setiap keinginan untuk memenuhi tuntutan zaman.

Pasal 260 UU Pilpres yang mengatur anggota TNI dan Polri tidak memiliki hak pilih dalam Pemilu. "Dalam Pemilu Presiden dan Wakil Presiden tahun 2009, anggota TNI dan Polri tidak menggunakan haknya untuk memilih". Sementara dalam Pasal 326 UU Nomor 8 Tahun 2012 tentang Pemilu Legislatif telah dinyatakan anggota TNI dan Polri tidak menggunakan hak pilihnya dalam Pemilu Legislatif tahun 2014. Padahal hak politik itu dijamin Pasal 28D Ayat (1) jo Pasal 1 Ayat (3) UUD NRI Tahun 1945.

Terkait dengan pembatasan tersebut, maka di dalam hubungan hukum antara negara dengan pegawai negeri khususnya personil TNI dan Polri terdapat ketentuan pembatasan perilaku bagi pegawai yang bekerja dalam instansi negeri. Hubungan ini disebut dengan hubungan dinas publik yang menurut Logemann, hubungan ini terjadi bilamana seseorang mengikatkan dirinya untuk tunduk pada suatu perintah dari pemerintah untuk melakukan sesuatu atau beberapa macam jabatan negeri yang dalam melakukan sesuatu atau beberapa macam jabatan negeri itu dihargai dengan pemberian gaji dan beberapa keuntungan lainnya. Hal ini berati bahwa inti dari hubungan dinas publik adalah kewajiban bagi pegawai yang bersangkutan untuk tunduk pada pengangkatan dalam beberapa macam jabatan tertentu yang berakibat bahwa pegawai yang bersangkutan tidak menolak (menerima tanpa syarat) pengangkatannya dalam satu jabatan yang telah ditentukan oleh pemerintah di mana sebaliknya pemerintah berhak mengangkat seseorang pegawai dalam jabatan tertentu tanpa harus adanya penyesuaian kehendak dari yang bersangkutan. Pada tingkat perundangan-undangan, UUD NRI Tahun 1945 Pasal 28 J Ayat (1) memberikan pembatasan dan kewajiban hak asasi manusia dengan menyatakan: "Setiap orang wajib menghormati hak asasi manusia orang lain dalam tertib kehidupan bermasyarakat, berbangsa dan bernegara".

Dalam konteks konstitusi, kebebasan dan kekuasaan merupakan dua hal yang berhadap-hadapan dan memiliki legitimasi yang sah. Kebebasan adalah hak asasi setiap orang yang harus dijamin dan dilindungi oleh karenanya sebagai suatu nilai, maka kebebasan harus diformulasikan dalam Konstitusi. Ketika kebebasan dijamin dalam Konstitusi, maka memaksa atau melarang seseorang yang hak dan kebebasannya dijamin oleh Konstitusi merupakan ketidakadilan,

${ }^{31}$ Setiajeng Kadarsih dan Tedi Sudrajat, op. cit, hlm. 55. 
sekaligus mengarah pada penyalahgunaan kekuasaan. Penyalahgunaan kekuasaan jelas bertentangan dengan hukum terutama dalam negara yang menjunjung tinggi konstitusionalisme. Oleh karena itu, pelanggaran terhadap hukum memerlukan penegakan hukum untuk menciptakan rasa adil dalam masyarakat. ${ }^{32}$

Pembatasan Hak Asasi Manusia dijumpai dalam piagam Hak Asasi Manusia yang tercantum dalam Ketetapan Majelis Permusyawaratan Rakyat No. XVII/MPR/1998 Pasal 34 yang menentukan bahwa setiap orang wajib menghormati hak asasi manusia orang lain dalam tertib kehidupan bermasyarakat, berbangsa, bernegara. Piagam Hak Asasi Manusia juga menegaskan bahwa penikmatan hak asasi manusia bisa dibatasi oleh hukum. Ditentukan oleh Pasal 36 dari Ketetapan MPR tersebut bahwa:

Di dalam menjalankan hak dan kebebasannya setiap orang wajib tunduk kepada pembatasan-pembatasan yang ditetapkan oleh Undang-Undang dengan maksud semata-mata untuk menjamin pengakuan serta penghormatan atas hak dan kebebasan orang lain, dan untuk memenuhi tuntutan yang adil sesuai dengan pertimbangan moral, keamanan dan ketertiban umum dalam suatu masyarakat demokratis.

Sementara itu Pasal 70 Undang-Undang No.39 Tahun 1999 tentang Hak Asasi Manusia juga mengatur limitasi hak asasi manusia dengan menentukan bahwa:

"Dalam menjalankan hak dan kebebasannya, setiap orang wajib tunduk kepada pembatasan yang ditetapkan Undang-Undang dengan maksud untuk menjamin pengakuan serta penghormatan atas hak dan kebebasan orang lain dan untuk memenuhi tuntutan yang adil sesuai dengan pertimbangan moral, kemanan, dan ketertiban umum dalam suatu masyarakat demokratis."

Hal tersebut bermakna bahwa pembatasan terhadap hak pilih dan dipilih bagi anggota TNI dan Polri dimaksudkan agar penyelenggaraan tugas pemerintah berupa pertahanan dan keamanan dilaksanakan secara penuh oleh anggota TNI dan Polri. Namun permasalahannya adalah perkembangan masyarakat demokratis di Indonesia semakin mengarah pada konsolidasi politik dalam hal pemberian hak yang sama pada setaip warga negara. ${ }^{33}$

Konsolidasi demokrasi adalah suatu proses pemapanan sistem demokrasi, untuk menuju pada sistem politik yang stabil dan mapan. Konsolidasi demokrasi memerlukan tiga hal, yaitu: pertama, pendalaman demokrasi (democratic deepenning), yakni struktur-struktur politik menjadi semakin terbuka (liberal),

\footnotetext{
32 Terpetik dari Ramly Hutabarat, Politik Hukum Pemerintahan Soeharto tentang Demokrasi Politik di Indonesia (1971-1997), (Jakarta: Pusat Studi Hukum Tata Negara Fakultas Hukum Universitas Indonesia, 2005), hlm. 225-226.

${ }^{33}$ Sumali, Urgensi TNI di Bingkai Konstitusi dalam Persepektif Yuridis Politis, Jurnal Hukum Republica, Vol. 3 No. 1, Tahun 2003, Pekanbaru: Fakultas Hukum Universitas Lancang Kuning, hlm. 61
} 
akuntabel, representatif dan fleksibel. Ini berarti kebebasan politik dijamin tetapi sekaligus juga tunduk pada hukum; kedua, pelembagaan politik (political institutionalization), yaitu terbangun dan tertatanya struktur-struktur politik dan pemerintahan untuk menjamin terselenggaranya birokrasi yang melayani kebutuhan publik, pemerintahan perwakilan yang mapan dan bertanggung jawab (partai politik, pemilu, badan-badan pemerintahan) yang mencerminkan pluralitas kepentingan masyarakat. Artinya, demokrasi akan dijadikan sebagai model dan aturan main bersama untuk menyelesaikan berbagai persoalan yang dihadapi baik secara sosial, politik, eknomi dan budaya. Oleh karena itu, salah satu ciri dari konsolidasi demokrasi adalah semakin kuatnya nilai-nilai demokrasi, khususnya jaminan kebebasan untuk berserikat dan berkumpul serta berorganisasi dan tidak adanya tekanan-tekanan politik oleh rezim menjadi salah satu dari sekian indikator. Konsolidasi demokrasi juga dicirikan oleh kuatnya pemahaman elit politik bahwa model demokrasi (sistem demokrasi) adalah pilihan satu-satunya bagi pelaksanaan dan mekanisme untuk melaksanakan pemerintahan. ${ }^{34}$

Posisi anggota TNI dan Polri dengan Pegawai Negeri Sipil (PNS) yang mempunyai hak pilih membuktikan adanya ketidak adilan dan diskriminasi. Penghilangan hak pilih merupakan diskriminasi terhadap anggota TNI dan Polri, karena pada kenyataannya PNS justru masih tetap menadapatkan haknya untuk memilih. Padahal anggota PNS dan TNI-Polri adalah pegawai negeri yang mempunyai kedudukan yang sama.

Mencermati relevansi dari substansi pengaturan tentang pembatasan penikmatan hak asasi manusia karena pertimbangan moral, nilai-nilai agama, keamanan dan ketertiban umum dalam suatu masyarakat demokratis apabila dikaitkan dengan hak pilih dan dipilih bagi anggota TNI dan Polri, maka pengaturan tersebut masih perlu untuk dievaluasi dengan pemikiran bahwa konsep demokrasi tersebut telah mencederai nilai-nilai ideal demokratis dengan adanya penghapusan hak asasi dan dihilangkannya keterwakilan lembaga TNI dan Polri dalam ranah politik. ${ }^{35}$

Dengan demikian, hak politik WNI yang kebetulan jadi anggota TNI dan Polri tidak dapat dihapuskan oleh siapapun, kecuali jika mereka tidak bersedia menggunakannya. Problematika dalam meletakkan supremasi hukum sebagai landasan utama berdemokrasi dan upaya penegakan keadilan tidak semata-mata terletak pada halangan struktural atas lemahnya political will penegak hukum dalam penegakan prinsip justice for all, tetapi juga pada sangat mudahnya norma hukum tidak saja belum terisi oleh nilai-nilai keadilan, tetapi hukum juga sering

\footnotetext{
${ }^{34}$ T. Hari Prihatono, 2008, Departemen Pertahanan-TNI-Masyarakat Sipil : Relasi dalam Formulasi Kebijakan dan Transparansi Implementasi, dalam diskusi untuk simposium "10 Tahun Reformsi Sektor Keamanan di Indonesia" dengan tema "Reformasi TNI dan Departemen Pertahanan RI Pasca Orde Baru di Indonesia”, yang diselenggarakan atas kerja sama Lesperrssi-HRWG-IDSPSSCAF, Hotel Sultan -Jakarta 28-29 Mei 2008

${ }^{35}$ Lihat Albert Hasibuan, Politik Hak Asasi Manusia (HAM) dan UUD 1945, (Law Review Fakultas Hukum Universitas Pelita Harapan, Vol. 8 No. 1 Juli 2008), hlm. 43-62.
} 
kali mengabdikan diri sebagai instrumen kekuasaan. ${ }^{36}$ Perlu ditegaskan bahwa hak pilih dan dipilih anggota TNI dan Polri pernah dilaksanakan pada Pemilu 1955 tanpa menimbulkan permasalahan dan gangguan keamanan sebagaimana dikhawatirkan sementara kalanganpada saat ini.

Kehawatiran tentang hak pilih dan dipilih anggota TNI dan Polri yang akan menyebabkan ketidaknetralan dalam Pemilu juga masih kurang berdasar.Sebab secara historis pada Pemilu pertama tahun 1955, anggota TNI dan Polri telah ikut berpartisipasi dalam arena politik dan tidak ada sesuatu hal yang mempengaruhi demokratisasi pada masa itu. Dalam optik Hak Asasi Manusia dan UUD NRI Tahun 1945, secara nyata dinyatakan bahwa hak ikut serta dalam Pemilu adalah fundamental right, hak tersebut telah dilindungi oleh konstitusi dan bersifat nonderogable right yang berlaku bagi seluruh warga negara tanpa terkecuali.

Anggota TNI dan Polri sebagai warga negara Indonesia sebagai pribadi mempunyai kedudukan yang sama dengan kalangan sipil lainnya. ${ }^{37}$ Bilamana dilihat kembali tentang kekhawatiran dari para kalangan sipil yang melarang TNI dan Polri dilarang mengeluarkan hak pilih dan dipilih, pendapat tersebut jauh dari kenyataan. Dikarenakan jumlah personel TNI dan Polri secara keseluruhan hanya sekitar 400.000, yang sangat kalah jauh dengan penduduk Indonesia secara keseluruhan. Hal ini mengartikan bahwa bila hak pilih TNI dan Polri itu mau diarahkan untuk memilih calon atau partai tertentu, hal teresebut tidak berpengaruh banyak terhadap perolehan suara. Kemudian bilamana ada kekhawatiran tentang penyalahgunaan wewenang tentu menjadi tugas politisi sipil supaya membuat peraturan perundang-undangan yang mengatur tentang penyalahgunaan tersebut.

Pelaksanaan Pemilu yang pertama kali pada tahun 1955, anggota TNI dan Polri ikut memilih dan dipilih. Dan pada catatan sejarah terbukti anggota TNI dan Polri pada masa itu tetap profesional dan netral dalam menjalankan fungsinya sebagai alat negara penegak hukum mewujudkan ketertiban dan keamanan masyarakat. Kebijakan Pemerintah yang melarang anggota TNI dan Polri untuk memberikan hak pilih dan dipilih merupakan diskriminasi terhadap warga negara karena pekerjaan dan status sosial. Padahal negara wajib memberikan perlakuan yang sama dan adil tanpa ada diskriminasi terhadap semua warga negara. Sebetulnya menurut UUD NRI Tahun 1945 TNI dan Polri mempunyai hak pilih dan dipilih. Namun hingga saat ini TNI dan Polri masih belum dapat menggunakan hak pilihnya dalam Pemilu 1999, 2004, 2009 dan 2014. Ke depannya mungkin saja hak pilih dan dipilih TNI-Polri dalam Pemilu dapat digunakan, jika sudah dicantumkan dalam UU Pemilu.

\section{KESIMPULAN}

\footnotetext{
${ }^{36}$ Marcus Priyo Gunarto, Perlindungan Hak Asasi Manusia dalam Dinamika Global, (Jurnal Mimbar Hukum, Vol. 19 No. 2, Juni 2007, Fakultas Hukum Universitas Gajah Mada), hlm. 259.

${ }^{37}$ Muhammad Gaussyah, Pencabutan Hak Pilih Polisi Dinilai Diskriminatif, www.hukumonline.com.htm, diakses tanggal 19 April 2014.
} 
Berdasarkan hasil kajian yang dilandasi oleh kerangka berpikir secara teoretikal dan analisis yuridikal atas pokok permasalahan sebagaimana telah diuraikan dalam tesis ini, maka dapatlah ditarik kesimpulan sebagai berikut:

(1) Anggota TNI dan Polri tidak diberi hak untuk memilih dan dipilih dalam Pemilu karena adanya kekahwatiran dari sebagian golongan masyarakat akan ketidaknetralannya dalam Pemilu. Hal tersebut dikarenakan anggota TNI dan Polri membawa senjata, yang berbeda dengan masyarakat sipil yang tidak membawa senjata, sehingga dapat dimaknai anggota TNI dan Polri itu mempunya kedudukan yang extraordinary. Secara teori memang anggota TNI dan Polri mempunyai hak yang sama dengan warga sipil lainnya. Karena posisi TNI dan Polri yang sama sebagai warga negara, namun secara praktik hal tersebut masih belum bisa dilaksanakan. Oleh sebab itu menjadi alternatif pemikiran yang ditawarkan dalam kajian ini;

(2) Konsep persamaan hukum bagi anggota TNI dan Polri dalam kebebasan berpolitik dilihat dari kesetaraan hak asasi manusia adalah dengan memberikan kebebasan bagi anggota TNI dan Polri untuk menggunakan hak pilihnya dalam pemilu legislatif maupun Presiden dan Wakil Presiden. Kemudian anggota TNI dan Polri yang mengajukan diri sebagai calon anggota legislatif, Presiden dan Wakil Presiden maka sama dengan Pegawai Negeri Sipil, yakni mengundurkan diri terlebih dahulu.

\section{SARAN-SARAN}

(1) Perlu dilakukan rekonseptualisasi dan perubahan terhadap hak memilih dan dipilih bagi TNI dan Polri. Hal ini merujuk kepada kaidah demokrasi secara universal, seseorang yang mempunyai profesi tertentu tidak kehilangan hak-hak politiknya, khususnya hak memilih dan dipilih dalam Pemilu. Semua warga negara pada prinsipnya mempunyai hak dan kewajiban yang sama untuk ikut serta dalam memajukan Negara.

(2) Upaya-upaya preventif dapat dilakukan pemerintah dalam rangka pemulihan hak memilih dan dipilih bagi anggota TNI dan Polri dapat berupa: Pertama, menumbuhkan sikap profesional pada anggota TNI dan Polri dalam menjalankan tugasnya. Kedua, memperbaiki kesejahteraan anggotanya terutama yang berpangkat rendah. Kesejahteraan dapat menghindarkan anggota TNI dan Polri dari kemungkinan pemanfaatan jasa mereka oleh pihak tertentu untuk meraih kepentingan pribadi atau golongan dalam bidang politik, khususnya pada saat Pemilu.

(3) Perlunya revisi/perubahan terhadap peraturan perundang-undangan yang mengatur hak pilih dan dipilih bagi anggota TNI dan Polri. Pertama, UU Nomor 34 Tahun 2004 tentang Tentara Nasional Indonesia Pasal 39 yang menyatakan bahwa prajurit dilarang terlibat dalam kegiatan untuk dipilih menjadi anggota legislatif dalam pemilihan umum dan jabatan politis lainnya. Kedua, UU No. 2 Tahun 2002 tentang Kepolisian Negara Republik Indonesia Pasal 28 Ayat (1) dan 
ayat (2) menyatakan bahwa: "Kepolisian Negara Republik Indonesia bersikap netral dalam kehidupan politik dan tidak melibatkan diri pada kegiatan politik praktis" serta "Anggota Kepolisian Negara Republik Indonesia tidak menggunakan hak memilih dan dipilih". Ketiga, Pasal 326 UU Nomor 8 Tahun 2012 tentang Pemilihan Umum Anggota DPR, DPD dan DPRD. Pasal tersebut menyatakan: " Dalam Pemilu tahun 2014, anggota Tentara Nasional Indonesia dan anggota Kepolisian Negara Republik Indonesia tidak menggunakan haknya untuk memilih". 


\section{F. DAFTAR PUSTAKA}

\section{A. Buku/LIteratur}

Benny K. Harman, Konfigurasi Politik dan Kekuasaan Kehakiman di Indonesia, Jakarta: ELSAM, 1997.

Ismail Sunny, Pergeseran Kekuasaan Eksekutif Suatu Penyelidikan dalam Hukum Tatanegara, Jakarta: Aksara Baru, 1986.

Jimly Asshiddiqie, Hukum Tata Negara dan Pilar-Pilar Demokrasi, Jakarta: Sinar Grafika, 2011.

Soedarsono, Mahkamah Konstitusi Sebagai Pengawal Demokrasi, Jakarta: Sekretariat Jenderal dan Kepaniteraan Mahkamah Konstitusi, 2005.

Tambunan, A.S.S. dkk, Dwifungsi ABRI, Cetakan Kedelapan, Yogyakarta: Gadjah Mada University Press, 1997.

Widodo Ekatjahjana, Lembaga Kepresidenan Dalam Sistem Ketatanegaraan Indonesia, Bandung : Pustaka Sutra, 2008.

\section{B. Disertasi/Tesis}

Hamid Attamimi, A., Peranan Keputusan Presiden Republik Indonesia dalam Penyelenggaraan Pemerintahan Negara (Desertasi), Jakarta : Pascasarjana UI, 1990.

I Gede Pantja Astawa, Hak Angket Dalam Sistem Ketatanegaraan Indonesia Menurut Undang-Undang Dasar 1945, (Disertasi), (Bandung: Universitas Padjadjaran, 2000.

Ibnu Tritjahjo, Pengaturan Pemisahan Pemilu Nasional dan Lokal Dalam Rangka Penyeleggaraan Otonomi Daerah yang Demokratis, (Disertasi), Malang: Universitas Brawijaya, 2007.

\section{Peraturan Perundang-Undangan}

Undang Undang Dasar Negara Republik Indonesia Tahun 1945.

Ketetapan Majelis Permusyawaratan Rakyat Republik Indonesia Nomor VI/MPR/2000 tentang Pemisahan Tentara Nasional Indonesia dan Kepolisian Negara Republik Indonesia.

Ketetapan Majelis Permusyawaratan Rakyat Nomor VII/MPR/2000 tentang Peran Tentara Nasional Indonesia dan Kepolisian Negara Republik Indonesia.

UU No. 7 Tahun 1953 tentang Pemilihan Anggota Konstituante dan Anggota Dewan Perwakilan Rakyat.

Undang-Undang Nomor 2 Tahun 2002 tentang Kepolisian Negara Republik Indonesia. 
Undang-Undang Nomor 7 Tahun 1953 tentang Pemilihan Anggota Konstituante dan Anggota Dewan Perwakilan Rakyat.

Undang-Undang Nomor 12 Tahun 2011 Tentang Pembentukan Peraturan Perundang-Undangan.

Undang-Undang Nomor 34 Tahun 2004 tentang Tentara Nasional Indonesia. Undang-Undang Nomor 39 Tahun 1999 Tentang Hak Asasi Manusia.

\section{Jurnal}

Hasnati, Pertautan Kekuasaan Politik dan Negara Hukum, Pekanbaru: Fakultas Hukum Universitas Lancang Kuning.

Hutabarat, Ramly, Politik Hukum Pemerintahan Soeharto tentang Demokrasi Politik di Indonesia (1971-1997), Jakarta: Pusat Studi Hukum Tata Negara Fakultas Hukum Universitas Indonesia, 2005.

Setiajeng Kadarsih dan Tedi Sudrajat, Analisis Terhadap Hak Pilih TNI dan Polri dalam Pemilihan Umum, (Fakultas Hukum Universitas Jenderal Soedirman Purwokerto, Jurnal Dinamika Hukum Vol. 11 No. 1 Januari, 2011.

\section{E. Kamus}

Ari Prahasta, Kamus Umum Bahasa Indonesia, Tangerang Selatan : Scientific Press. Campbell Black, Henry, Black's Law Disctionary, United States of America: West Publishing CO, 1990.

\section{F. Internet :}

Muhammad Gaussyah, Pencabutan Hak Pilih Polisi Dinilai Diskriminatif, www.hukumonline.com.htm, diakses tanggal 19 April 2014. 